\title{
Origoinal Artiticle
}

\section{Quantitative assessment of elastic fibers in chronic obstructive pulmonary disease ${ }^{*}$}

\author{
Rogerio Rufino', Kalil Madi², Heitor Siffert Pereira de Souza ${ }^{3}$, Cláudia Henrique da Costa', \\ Eduardo Haruo Saito ${ }^{4}$, José Roberto Lapa e Silva ${ }^{5}$
}

\begin{abstract}
Objective: To quantify elastic fibers (EFs) and smooth muscle (SM) cells, as well as $\mathrm{CD}^{+}$and $\mathrm{CD}^{+} \mathrm{T}$ lymphocytes, in stable chronic obstructive pulmonary disease (COPD). Methods: Surgical specimens were obtained from 15 COPD patients, 18 smokers without airflow limitation, and 14 nonsmokers. Histological and immunohistochemical methods were employed in order to quantify EFs, SM cells, CD4 ${ }^{+} \mathrm{T}$ cells, and CD8+ T cells. Results: There was no significant difference in EF numbers among the three groups ( $p>0.05)$. The number of EFs per unit area of lung tissue $\left(\mathrm{mm}^{2}\right)$ and the percentage of EFs in the lung tissue were similar among the three groups. The numbers of SM cells were found to be higher in the COPD patients than in the smokers $(p=0.003)$ or in the nonsmokers $(p=0.009)$. There was a tendency toward an increase in CD8 ${ }^{+}$T-cell counts in the COPD patients. In specimens collected from the COPD patients, CD4 ${ }^{+}$T-cell counts were lower than in those collected from the smokers $(p=0.015)$ or from the nonsmokers $(p=0.003)$. There was a weak correlation between CD4 ${ }^{+} \mathrm{T}$-cell count and the ratio of forced expiratory volume in one second to forced vital capacity $\left(\mathrm{r}^{2}=0.003\right)$. Conclusions: The EF counts were similar among the three groups. Hypertrophy/hyperplasia of airway wall SM cells was found in the COPD patients and in the smokers, indicating that airway remodeling occurs in smokers. The CD4/CD8 ratio was lower in the COPD patients.
\end{abstract}

Keywords: Pulmonary disease, chronic obstructive; CD4 Lymphocyte Count; Elastic tissue; Muscle, smooth.

\footnotetext{
* Study carried out at the Research Multidisciplinary Laboratory of the Universidade Federal do Rio de Janeiro - UFRJ, Federal University of Rio de Janeiro - Rio de Janeiro (RJ) Brazil.

1. Adjunct Professor of Pulmonology and Phthisiology at the School of Medical Sciences of the Universidade do Estado do Rio de Janeiro - UERJ, State University of Rio de Janeiro - Rio de Janeiro (RJ) Brazil.

2. Full Professor in the Department of Pathology of the Universidade Federal do Rio de Janeiro - UFRJ, Federal University of Rio de Janeiro - School of Medicine, Rio de Janeiro (RJ) Brazil.

3. Adjunct Professor of Clinical Medicine at the Universidade Federal do Rio de Janeiro - UFRJ, Federal University of Rio de Janeiro - School of Medicine, Rio de Janeiro (RJ) Brazil.

4. Adjunct Professor of Thoracic Surgery at the School of Medical Sciences of the Universidade do Estado do Rio de Janeiro - UERJ, State University of Rio de Janeiro - Rio de Janeiro (RJ) Brazil.

5. Full Professor of Pulmonology and Phthisiology at the Universidade Federal do Rio de Janeiro - UFRJ, Federal University of Rio de Janeiro - School of Medicine, Rio de Janeiro (RJ) Brazil.

Correspondence to: José Roberto Lapa e Silva. Laboratório Multidisciplinar, Hospital Universitário Clementino Fraga Filho, Universidade Federal do Rio de Janeiro, Av. Brigadeiro Tromposki, s/n, llha do Fundão, CEP 21941-590, Rio de Janeiro, RJ, Brasil.

Tel 5521 2562-2669. Fax 5521 2290-3520. E-mail: jrlapa.ntg@terra.com.br

Submitted: 29 November 2006. Accepted, after review: 24 January 2007.
} 


\section{Introduction}

The prevalence of chronic obstructive pulmonary disease (COPD), as well as the COPD-related mortality rate, has increased worldwide. The World Health Organization predicts that in the year 2020 COPD will become the fifth most prevalent disease and the third leading cause of mortality. ${ }^{(1)}$ Currently, COPD is defined as a chronic inflammatory disease, characterized by a slow decline in pulmonary function, which does not respond adequately to drug treatment.

The lung reacts to the aggressions caused by the toxic gases most frequently related to smoking by presenting an inflammatory response. Cells such as macrophages, neutrophils and lymphocytes are recruited. In addition, oxidative substances, antioxidative substances and immunological mediators are liberated, interfering with the function and modifying the structure of the parenchyma and the airways. This inflammation therefore promotes parenchymal and airway remodeling. ${ }^{(2-4)}$

The role of each of these inflammatory cells in the structural alteration caused by the disease has not yet been fully established. In some circumstances, such as infection or smoking, the neutrophils migrate to the lung in great numbers. During this process, the neutrophils might liberate their enzymes for pulmonary preservation. Therefore, neutrophilic substances are liberated in great quantity, acting in the recognized sites of their enzymatic interaction, without distinction between harmful substances or extracellular matrix components. ${ }^{(5,6)}$

Neutrophilic lysosomal elastase is the principal enzyme involved in the degradation of elastin, a component of elastic fibers. Under normal conditions, the proteolytic enzyme activity is prevented and restored by the antiproteolytic enzymes. ${ }^{(7-9)}$ This fact has stimulated some researchers to produce emphysema models involving high concentrations of elastase or alpha- 1 antitrypsin deficiency. ${ }^{(9-11)}$ However, the correlation between these inflammatory models and the structural alterations produced by them is not simple or direct. Not all smokers presenting high neutrophil counts in their airways develop emphysema, suggesting that the neutrophils are not the only cells that participate in this process.

Recently, T lymphocytes, especially CD8 ${ }^{+} \mathrm{T}$ cells, have been found in the alveoli and in the bronchial walls of COPD patients. ${ }^{(3,11)}$ Although it is known that these cells have direct participation against viruses and parasites, no correlation with alterations of elastic fibers has been established.

The objective of this study was to quantify the elastic fibers in pulmonary biopsies and to investigate their correlation with $\mathrm{CD}^{+} \mathrm{T}$ cells in COPD patients.

\section{Methods}

A cross-sectional study, involving 47 patients submitted to thoracic surgery, was carried out from 2001 to 2005. The protocol was approved by the Ethics in Research Committee of the Clementino Fraga Filho University Hospital of the Federal University of Rio de Janeiro, and all patients gave written informed consent prior to the surgery. To be included in the study, the patients were required to submit to the following: anamnesis; physical examination; chest $\mathrm{X}$-ray; spirometry; determination of alpha-1 antitrypsin level; serologic testing for HIV; and pulmonary biopsy during the surgery. The following exclusion criteria were established: history of atopy; positive bronchodilator response in the spirometry tests; pulmonary infection within the last four weeks; alpha-1 antitrypsin levels below the range of normality; seropositivity for HIV antibodies; radiological evidence of infiltrative or inflammatory alterations, or a conclusion by one of the three pathologists involved in the protocol that the samples were infiltrated by neoplastic or inflammatory tissue.

\section{Study groups}

The patients were divided into three groups, taking into account the ratio between forced expiratory volume in one second $\left(\mathrm{FEV}_{1}\right)$ and forced vital capacity (FVC):

1) COPD: patients presenting a more than 20 pack-year history of smoking, with no history of atopy, $\mathrm{FEV}_{1} / \mathrm{FVC}<70 \%$, and negative bronchodilator test, according to the American Thoracic Society (ATS) criteria; ${ }^{(12)}$

2) Smokers: patients presenting a smoking history of more than 20 pack-years, with not history of atopy, $\mathrm{FEV}_{1} / \mathrm{FVC}>70 \%, \mathrm{FEV}_{1}>80 \%$ and negative bronchodilator test, according to the ATS criteria; ${ }^{(12)}$ 
3) Nonsmokers: patients with no history of smoking or atopy, $\mathrm{FEV}_{1} / \mathrm{FVC}>70 \%$, $\mathrm{FEV}_{1}>80 \%$ and negative bronchodilator test, according to the ATS criteria. ${ }^{(12)}$

\section{Histology}

Samples of pulmonary tissue measuring between 1 and $3 \mathrm{~cm}^{3}$ were obtained surgically, avoiding the areas involved by the tumor. Each specimen was divided into two parts: the first was fixed in 10\% formaldehyde solution, dehydrated and placed in paraffin, for the histological study; the second was frozen in liquid nitrogen and maintained at $-80^{\circ} \mathrm{C}$, for the immunohistochemical study. Ten slides with $5-\mu \mathrm{m}$-thick sections were prepared both for the histological study and for the immunohistochemical study; the sections for the latter were cut on a cryostat $\left(-24^{\circ} \mathrm{C}\right)$ and mounted on poly-L-lysine coated slides, dried at room temperature, cooled, sealed with plastic film and stored at $-20{ }^{\circ} \mathrm{C}$ for later analyses with immunomarkers.

\section{Morphometric analyses}

The morphometric measurements were taken in slides stained with Masson's trichrome technique and Weigert's resorcin-fuchsin technique in order to identify smooth muscle cells and elastic fibers, respectively. ${ }^{(13)}$ The readings were taken using an optical microscope (magnification, $\times 100$, Microstar IV; Reichert/Leica, Depew, NY, USA) connected to a computed image system (Image-pro Plus v. 4.1; Media Cybernetics, Silver Spring, MD, USA). The slides were coded and analyzed without the knowledge of the groups to which they belonged and at least $2 \mathrm{~mm}^{2}$ of material were examined on each slide, composed of 10 or more fields seen with 10× objective.

Due to the heterogeneity of the specimens (areas that are more or less inflated), a correction model (Image-pro Plus) was used, quantifying the elastic fibers and the muscle fibers exclusively by area of pulmonary tissue, without calculating the air space. The regions were selected considering the quality of the sample, avoiding subpleural areas and areas near bronchioles and vessels, that is, exclusively parenchyma.

The results were presented by both the quantity of elastic fibers and muscle fibers calculated by unit area of pulmonary tissue $\left(\mathrm{mm}^{2}\right)$ and by its percentage in relation to the total.

The immunohistochemical staining was performed using the avidin-biotin immunoperoxidase technique (Vector Laboratories, Burlingame, CA, USA) to stain $5-\mu \mathrm{m}$ sections fixed in acetone. We used human monoclonal antibodies CD4+ (clone QA4120, code C-1805, lot 116H4875; Sigma Chemical, St. Louis, MO, USA) and CD8 ${ }^{+}$ (clone UCH-4, code C-7423, lot 40K4830; Sigma Chemical), and used the point-counting technique. Immunoglobulin of mice was used as negative controls.

All histological analyses were performed by two independent observers (Figure 1).

\section{Statistical analysis}

Initially, the distribution of the samples was analyzed using the Kolmogorov-Smirnov test, the kurtosis coefficient, and the skewness coefficient. Subsequently, evaluating the sample distribution, we chose the non-parametric Mann-Whitney test and the two-tailed test for the analysis, always considering statistical significance when $p<0.05$. The statistical correlations were made using Spearman's test.

\section{Results}

We analyzed 47 patients: 15 with COPD, 18 smokers, and 14 nonsmokers. In the group of COPD patients, 6 cases were considered mild and 9 moderate, according to the criteria established by the Global Initiative for Chronic Obstructive Lung Disease. ${ }^{(2)}$ The age was significantly greater in the COPD group $(p<0.05)$, in which all of the patients had non-small cell lung cancer - at stages $1 \mathrm{~b}$ $(n=3)$, 1la $(n=5)$ or $11 b(n=4)$ - or small cell lung cancer restricted to the chest $(n=3)$. The same was observed in the group of smokers (among whom only one patient had been diagnosed with another disease), who also presented non-small cell carcinoma - at stages la $(n=2), 1 b(n=3), 11 a(n=4)$ or $1 \mathrm{lb}(\mathrm{n}=6)$ - or small cell carcinoma restricted to the chest $(n=2)$. In the group of nonsmokers, the patients had non-small cell cancer at stages lla $(n=4)$ or $11 \mathrm{~b}(n=2)$, small cell cancer restricted to the chest $(n=1)$, tuberculosis $(n=4)$, pneumothorax $(n=2)$ or bronchiectasis $(n=1)$ (Table 1$)$.

There was no statistical difference in the quantification (percentage and absolute) of the elastic 


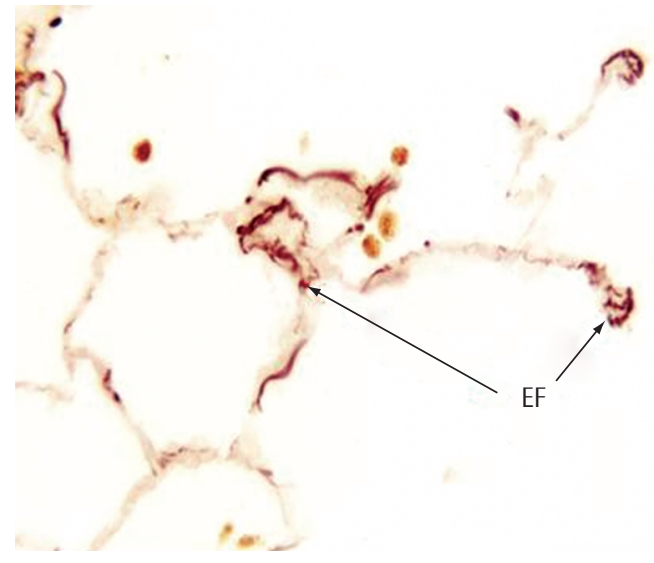

(a)
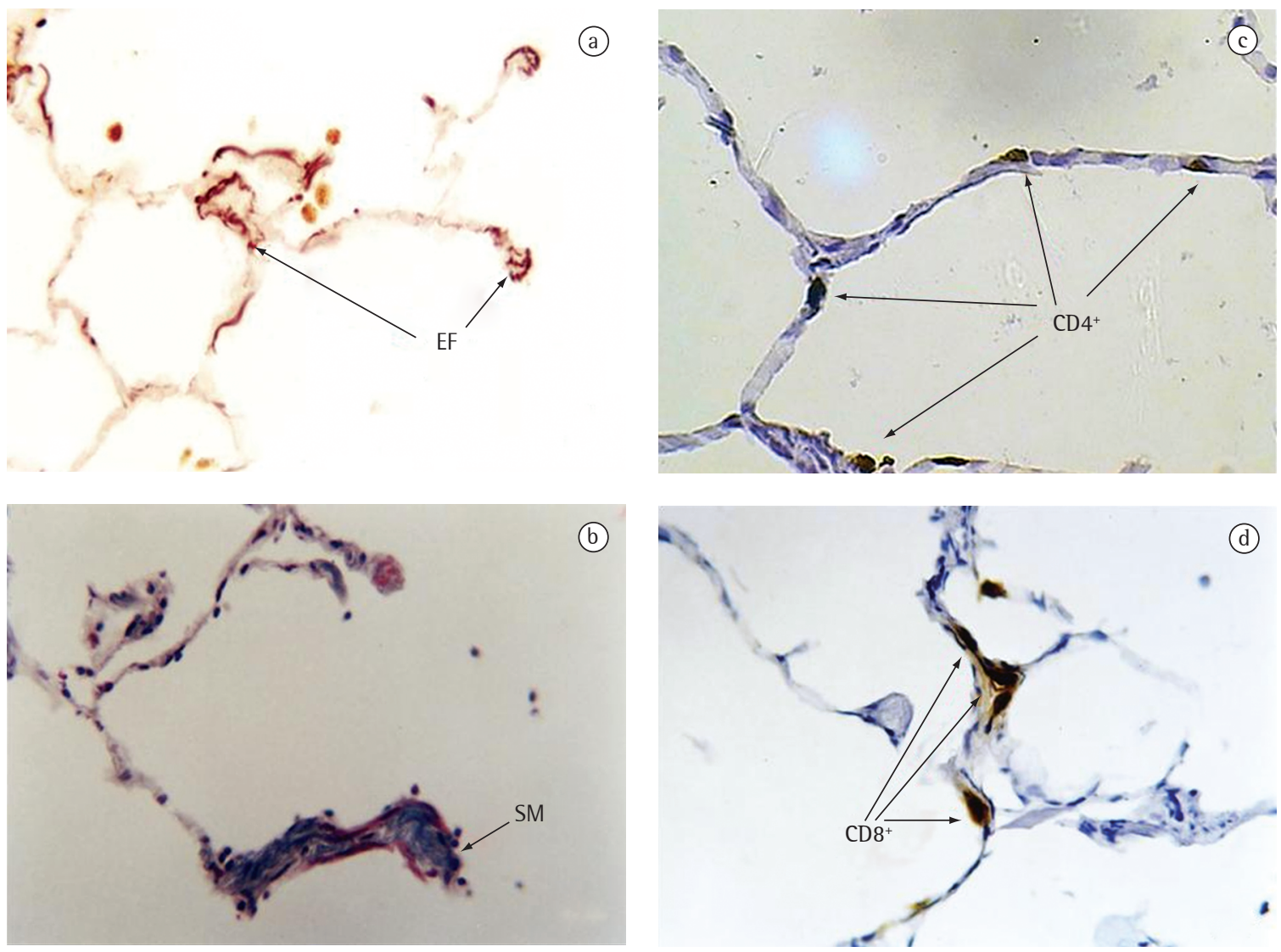

Figure 1 - Panel of the histological and immunohistochemical techniques of a patient from the chronic obstructive pulmonary disease group: a) Weigert's resorcin-fuchsin staining technique showing the elastic fibers (EF) that are discontinuously displaced with various sizes and irregularly distributed in the alveolar septum (Magnification $\times 400$ ); b) Masson's trichrome staining technique, showing the smooth muscle cells (SM) that increase the diameter of the alveolar walls, forming a drum stick image (Magnification 400×); c) CD4 ${ }^{+}$staining with immunoperoxidase technique showing the lymphocytes resting and occupying practically the entire line of the alveolar septum (Magnification, $\times 400$ ); and d) $\mathrm{CD}^{+}$staining with immunoperoxidase technique, showing a tendency toward a grouping of the lymphocytes in the alveolar septum (Magnification $\times 400$ ).

fibers among the three groups (Table 2 and Figure 2), and their linear regression with $\mathrm{FEV}_{1} / \mathrm{FVC}$ $\left(r^{2}=0.003\right)$, smooth muscle fibers $\left(r^{2}=0.006\right), C D 4^{+}$ T lymphocytes $\left(r^{2}=0.005\right)$ and $C D 8^{+} T$ lymphocytes $\left(r^{2}=0.054\right)$ demonstrated a weak correlation.

As for the smooth muscle cells, it was observed that, in the group of COPD patients and in that of smokers, there was an increase in the quantity of these fibers in comparison with the group of nonsmokers ( $p=0.003$ and $p=0.009$, respectively) (Table 2 and Figure 2). In the linear regression, the quantity of smooth muscle cells correlated weakly with the $F E V_{1} / F V C$ ratio $\left(r^{2}=0.059\right)$, as it did with the total number of $C D 4^{+} \mathrm{T}$ cells $\left(\mathrm{r}^{2}=0.013\right)$ and CD8 ${ }^{+} \mathrm{T}$ cells $\left(\mathrm{r}^{2}=0.005\right)$.

The $\mathrm{CD} 4^{+} \mathrm{T}$-lymphocyte counts were lower in the COPD patients than in the nonsmokers $(p=0.003)$ (Table 2 and Figure 3).

No significant increase was observed in $\mathrm{CD}^{+} \mathrm{T}$ lymphocytes, although the CD4/CD8 ratio was significantly lower in the COPD patients than in the nonsmokers $(p<0.005)$ (Table 2 and Figure 3$)$.

\section{Discussion}

What differentiates COPD from many noninfectious inflammatory lung diseases it that it is 
Table 1 - Demographic and spirometric data.

\begin{tabular}{lccc}
\hline Variable & \multicolumn{3}{c}{ Group } \\
\cline { 2 - 4 } & $\begin{array}{c}\text { Nonsmokers } \\
(\mathrm{n}=14)\end{array}$ & $\begin{array}{c}\text { Smokers } \\
(\mathrm{n}=18)\end{array}$ & $\begin{array}{c}\text { COPD } \\
(\mathrm{n}=15)\end{array}$ \\
\hline Age (years) & $46.71 \pm 17.85^{\mathrm{a}}$ & $60.39 \pm 11.55$ & $61.20 \pm 11.11^{\mathrm{a}}$ \\
Gender (F/M) & $8 / 6$ & $8 / 10$ & $1 / 14$ \\
Cancer cases & 7 & 17 & 15 \\
Other diseases & 7 & 1 & 0 \\
FEV $(\mathrm{L})$ & $2.73 \pm 1.00$ & $2.49 \pm 1.00$ & $2.34 \pm 0.32$ \\
FVC (L) & $3.22 \pm 1.06$ & $3.10 \pm 0.56$ & $3.58 \pm 0.59$ \\
FEV $/$ FVC (\%) & $84.18 \pm 7.21^{\mathrm{b}}$ & $79.91 \pm 6.98^{\mathrm{b}}$ & $63.46 \pm 5.20^{\mathrm{b}}$ \\
\hline
\end{tabular}

COPD: chronic obstructive pulmonary disease; F: female; M: male; FEV : forced expiratory volume in one second; FVC: forced vital capacity; and $\mathrm{FEV}_{1} / \mathrm{FVC}$ : the ratio between $\mathrm{FEV}_{1}$ and $\mathrm{FVC} ;{ }^{a} \mathrm{p}<0.05$ nonsmokers $v s$. COPD; and ${ }^{\mathrm{b}} \mathrm{p}<0.05$ nonsmokers and smokers vs. COPD.

characterized by a tenuous and chronic inflammation, with phenotypical expression of $\mathrm{CD}^{+}$ immunological cells. In addition, there is an imbalance of proteolytic and oxidant substances which act preferably in the more distal areas of the lung.

Our study did not demonstrate statistical difference in the content of elastic fibers in the analyzed groups, in the absolute/percentage counts of the elastic fibers or in the count corrected by the total tissue area.

The imbalance of the proteolytic and antiproteolytic enzymes as a model of COPD development has not yet been fully established in the pulmonary emphysema without the hereditary alpha-1 antitrypsin deficiency. Experimental models of emphysema use elevated quantities of proteolytic enzymes, which most closely mimics alpha- 1 antitrypsin deficiency. ${ }^{(8,14)}$

In the 1970s, certain authors ${ }^{(15-17)}$ reported that the elastic fibers 'seemed reduced' by 'degeneration or destruction' in COPD. Other authors ${ }^{(18)}$ performed necropsies in 10 patients with COPD and 9 without lung disease and reported that the elastic fibers were similar in the two groups in terms of quantity. In an experimental study involving the instillation of elastase into the tracheas of pigs, ${ }^{(19)}$ it was observed that, after four months, the quantity of elastic fibers was not significantly different from that of the control group. However, the instillation group demonstrated an abnormal configuration accompanied by disorganization of the elastic fibers. In another study, ${ }^{(20)}$ instillations of elastase were made in rats, and structural analyses of the elastic fibers were carried out using electron micro- scopy, under which fenestrations and fractures were seen. Supposedly, they were disconnected and not involved with the functionality of the respiratory system. In yet another study, ${ }^{(21)}$ the ELISA method was used in order to analyze the peptides derived from the degradation of the elastic fibers in COPD patients, smokers and nonsmokers. The authors demonstrated that there was a significant increase in the peptides in the group of COPD patients. In a study ${ }^{(22)}$ presenting data similar to those of the previous one, ${ }^{(21)}$ urinary levels of desmosine and isodesmosine, which are products of elastin degradation, were significantly higher in patients with COPD than in nonsmokers. The elevated values of the metabolites of the elastic fibers found in the urine and blood of the smokers and COPD patients might represent the process of regeneration of the elastic content. ${ }^{(23)}$ It should not be forgotten that these products of degradation are not specific of the pulmonary elastic fibers, but they represent all the elastic fibers of the human body and that the values of these metabolites are usually higher in older individuals, which might make it difficult to value these findings in COPD patients, who are normally at advanced ages.

In the present study, smooth muscle cells were seen in the distal airways, with a progressive increase and with statistical significance in the smokers ( $p=0.009)$ and in that of the COPD patients $(p=0.003)$. There was poor statistical correlation between the quantity of smooth muscle cells and the FEV, FVC ratio $\left(r^{2}=-0.059\right.$ and $\left.p=0.017\right)$.

Two studies ${ }^{(24,25)}$ demonstrated that, in the respiratory and membranous bronchioles of the smokers 
Table 2 - Histometric and cellular findings.

\begin{tabular}{lccc}
\hline \multicolumn{1}{c}{ Variable } & \multicolumn{3}{c}{ Group } \\
\cline { 2 - 4 } & Nonsmokers & Smokers & COPD \\
\hline Elastic fibers $\left(\mathrm{mm}^{2}\right)$ & $0.0459(0.0078-0.1221)$ & $0.0662(0.0181-0.2558)$ & $0.0611(0.0109-0.2451)$ \\
Elastic fibers $(\%)$ & $21.54 \pm 12.00$ & $20.03 \pm 10.20$ & $18.47 \pm 7.59$ \\
Smooth muscle $\left(\mathrm{mm}^{2}\right)$ & $0.0237^{\mathrm{a}}(0.0089-0.0775)$ & $0.0521^{\mathrm{a}}(0.0148-0.1302)$ & $0.0660^{\mathrm{a}}(0.0269-0.1473)$ \\
Smooth muscle $(\%)$ & $10.06 \pm 22.00^{\mathrm{a}}$ & $16.40 \pm 18.65$ & $20.72 \pm 30.12^{\mathrm{a}}$ \\
$\mathrm{CD}^{+}\left(\mathrm{mm}^{2}\right)$ & $104.79^{\mathrm{b}}(11-105)$ & $86.11(13-116)$ & $45.07^{\mathrm{b}}(18-211)$ \\
$\mathrm{CD}^{+}\left(\mathrm{mm}^{2}\right)$ & $42.50(27-219)$ & $48.50(14-368)$ & $61.20(27-411)$ \\
CD4/CD8 $\left(\mathrm{mm}^{2}\right)$ & $3.08^{\mathrm{c}}(0.41-7.30)$ & $2.04^{\mathrm{c}}(0.54-7.36)$ & $1.02^{\mathrm{c}}(0.61-3.12)$ \\
\hline
\end{tabular}

COPD: chronic obstructive pulmonary disease; The results in $\mathrm{mm}^{2}$ represent the median, together with the minimal and maximal

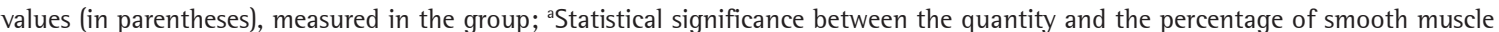
cells in the airways in the nonsmokers and smokers $(p=0.009)$ and in the COPD group $(p=0.003)$; ${ }^{b}$ Significant reduction in the number of $\mathrm{CD}^{+} \mathrm{T}$ cells in the COPD group in comparison with the nonsmokers (control) group ( $\mathrm{p}=0.003$ ); and ${ }^{\mathrm{C}}$ The $\mathrm{CD} 4 / \mathrm{CD} 8$ ratio decreased in the COPD and smokers groups in comparison with the nonsmokers group $(p<0.005)$.

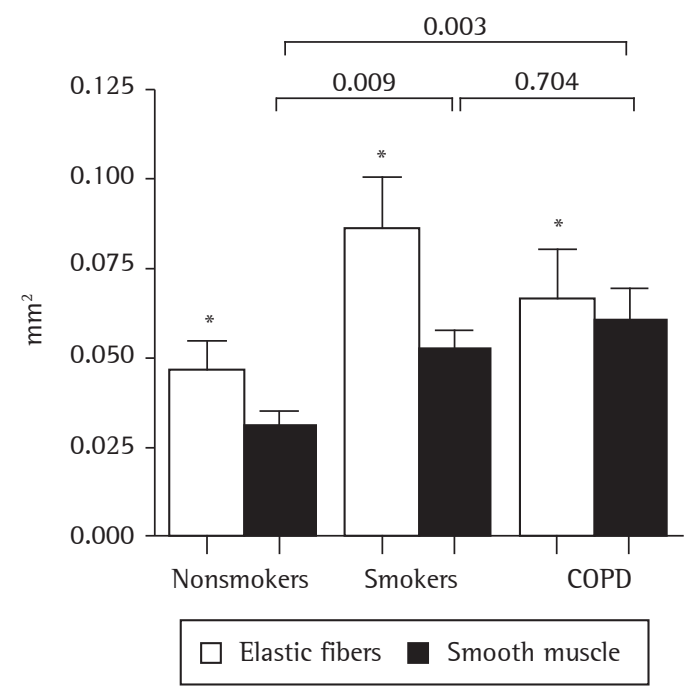

Figure 2 - Values of the elastic fibers and of the smooth muscle. There was increase in the bronchiolar smooth muscle cells both in the smokers group and in the chronic obstructive pulmonary disease (COPD) group in comparison with the nonsmokers (control) group; and *There was no statistical difference in the quantification of the elastic fibers among the groups ( $p>0.05)$.

and of the COPD patients, there was cellular infiltrate, increase in the goblet cells and in the muscle cells. In another study, ${ }^{(26)}$ it was reported that the quantity of bronchioles smaller than $2 \mathrm{~mm}$ remained similar in percentage in the COPD patients, smokers and nonsmokers. However, when the bronchioles were grouped according to their dimensions, it was determined that in the COPD group there was a

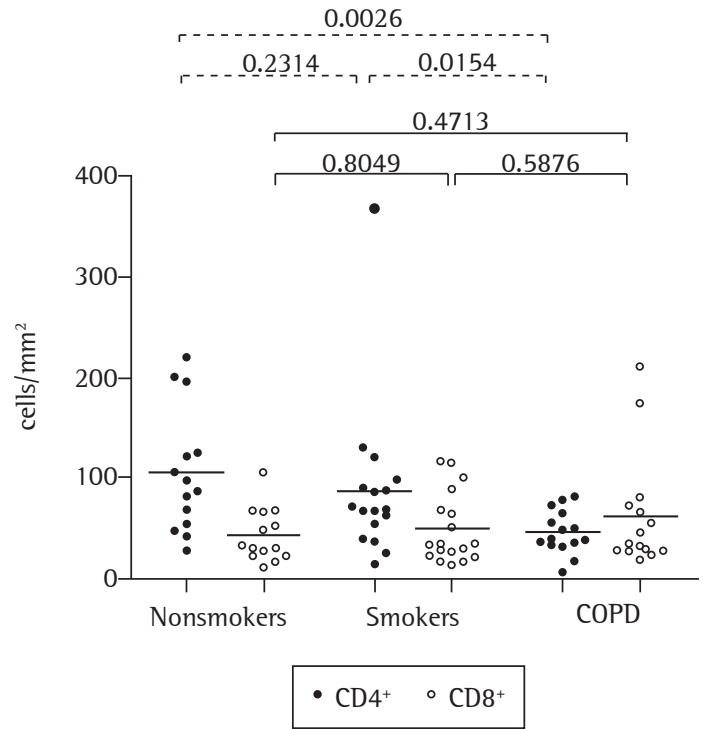

Figure 3 - Values of $\mathrm{CD}^{+}$and $\mathrm{CD} 8^{+} \mathrm{T}$ lymphocytes. There was a decrease in the median values of the total number of $\mathrm{CD}^{+}$cells in the smokers and in the chronic obstructive pulmonary disease (COPD) group. There was a nonsignificant increase in the median values of the total number of $\mathrm{CD}^{+}$cells in the smokers and in the COPD group; and Each black dot or white dot represents the value of $\mathrm{CD}_{4}^{+}$or $\mathrm{CD}^{+}$, respectively, and the small horizontal line shows the median value of $\mathrm{CD}^{+}$or $\mathrm{CD}^{+}$ in each analyzed group.

significant increase in bronchioles with diameters smaller than $400 \mu \mathrm{m}$ in comparison with the other two groups. Another study ${ }^{(27)}$ demonstrated the relationship of the diameter of the small respiratory ways with the airflow obstruction, correlating the increase in the bronchial wall with reduction in 
the bronchiolar lumen and, as a consequence, the elevation of the airway resistance and the airflow obstruction. In that study, the COPD patients had a greater number of bronchioles with smaller lumen diameters.

The sites of muscle mass increase are different in the two principal obstructive lung diseases. In asthma, the distribution of the muscle hypertrophy/ hyperplasia occurs preferably in the large airways. In the COPD, the muscle hypertrophy/hyperplasia occurs in the small airways. This muscle distribution might contribute to the pathophysiological differences of COPD. ${ }^{(26,27)}$

Differently from the report described by some researchers, ${ }^{(28)}$ the quantitative analysis of $\mathrm{CD}^{+} \mathrm{T}$ cells in the COPD group, in comparison with the nonsmokers, was significantly reduced $(p=0.003)$. The CD4/CD8 ratio was statistically lower in the COPD group in comparison with the nonsmokers ( $p<0.005)$. In the COPD group, there was also a tendency toward an increase in $\mathrm{CD} 8^{+}$cells and a weak correlation between the number of $\mathrm{CD}^{+}$cells and the $\mathrm{FEV}_{1} / \mathrm{FVC}$ ratio.

Recently, it has been demonstrated that the reversibility phenomenon (bronchial response) depends on the characteristics of the inflammatory process. The increase in $\mathrm{CD}^{+}$cells or the combination of the increase in $\mathrm{CD}^{+}$cells with the depletion of $\mathrm{CD}^{+}$cells are stimuli that increase the bronchial muscle response, and lower concentrations of $\mathrm{CD}^{+}$ T lymphocytes reduce the response. ${ }^{(29)}$

An in vitro study conducted in the bronchiolar muscle of patients with asthma and of COPD patients demonstrated that the bronchiolar muscle responded to the drugs with the same intensity and, therefore, there was no qualitative difference of the muscle in asthma and in COPD.

In conclusion, we did not observe quantitative reduction of the elastic fibers in COPD patients, suggesting that, if altered, they produce dysfunction. The elastic fibers have a long half-life and are very resistant to degradation/natural reabsorption, and this might explain why they were found in the same quantities in the lungs of COPD patients and in nonsmokers.

The increase in the parenchymal muscle fibers in COPD patients and in the smokers was pronounced, demonstrating that lung remodeling also occurs in smokers and that this increase in isolation cannot be responsible for the airflow limitation.
No correlation of $\mathrm{CD}^{+}$or $\mathrm{CD}^{+} \mathrm{T}$ lymphocytes with the quantity of elastic fibers and smooth muscle cells was found. Our data demonstrated that there is a modification of the lymphocyte and inflammatory profile in the COPD, verified in the reduction of the $\mathrm{CD}^{+} / \mathrm{CD}^{+}{ }^{+}$T-lymphocyte ratio.

\section{References}

1. Donaldson GC, Seemungal TA, Bhowmik A, Wedzicha JA. Relationship between exacerbation frequency and lung function decline in chronic obstructive pulmonary disease. Thorax. 2002;57(10):847-52.

2. GOLD - Global strategy for the diagnosis, management, and prevention of chronic obstructive pulmonary disease [Homepage on the Internet]. Executive Summary, Global Strategy for the Diagnosis, Management, and Prevention of COPD Updated 2005 [cited 2006 Nov 19]. Available from: http://www.goldcopd.org/Guidelineitem. asp? $11=2 \mathrm{etl} 2=1$ Etintld $=1662$

3. Hogg JC, Chu F, Utokaparch S, Woods R, Elliott WM, Buzatu $\mathrm{L}$, et al. The nature of small-airway obstruction in chronic obstructive pulmonary disease. N Engl J Med. 2004 Jun 24;350(26):2645-53.

4. Barnes PJ. Mediators of chronic obstructive pulmonary disease. Pharmacol Rev. 2004;56(4):515-48.

5. O'Donnell RA, Peebles C, Ward JA, Daraker A, Angco G, Broberg P, et al. Relationship between peripheral airway dysfunction, airway obstruction, and neutrophilic inflammation in COPD. Thorax. 2004;59(10):837-42.

6. Fabbri LM, Romagnoli M, Corbetta L, Casoni G, Busljetic $\mathrm{K}$, Turato G, et al. Differences in airway inflammation in patients with fixed airflow obstruction due to asthma or chronic obstructive pulmonary disease. Am J Respir Crit Care Med. 2003;167(3):418-24..

7. Fehrenbach H. Animal models of chronic obstructive pulmonary disease: some critical remarks. Pathobiology. 2002-2003;70(5):277-83.

8. Corteling R, Wyss D, Trifilieff A. In vivo models of lung neutrophil activation. Comparison of mice and hamsters. BMC Pharmacol. 2002;2:1.

9. Takubo Y, Guerassimov A, Ghezzo H, Triantafillopoulos A, Bates JH, Hoidal JR, et al. Alpha1-antitrypsin determines the pattern of emphysema and function in tobacco smokeexposed mice: parallels with human disease. Am J Respir Crit Care Med. 2002;166(12 Pt 1):1596-603.

10. Abusriwil H, Stockley RA. Alpha-1-antitrypsin replacement therapy: current status. Curr Opin Pulm Med. 2006;12(2):125-31.

11. Hogg JC. Pathophysiology of airflow limitation in chronic obstructive pulmonary disease. Lancet. 2004;364(9435):709-21.

12. Lung function testing: selection of reference values and interpretative strategies. American Thoracic Society. Am Rev Respir Dis. 1991;144(5):1202-18.

13. Armed Forces Institute of Pathology. Stains for connective Tissue. In: Armed Forces Institute of Pathology. Manual of Histologic and special staining technique. 2nd ed. New York: McGraw-Hill Book Company; 1949. p. 55-96. 
14. Cosio MG, Majo J, Cosio MG. Inflammation of the airways and lung parenchyma in COPD: role of $\mathrm{T}$ cells. Chest. 2002;121(5 Suppl):160S-165S.

15. Wright RR. Elastic tissue of normal and emphysematous lungs. A tridimensional histologic study. Am J Pathol. 1961;39:355-67.

16. Thurlbeck WM. Measurement of pulmonary emphysema. Am Rev Respir Dis. 1967;95(5):752-64.

17. Kaplan PD, Kuhn C, Pierce JA. The induction of emphysema with elastase. 1. The evolution of the lesion and the influence of serum. J Lab Clin Med. 1973;82(3):349-56.

18. Pierce JA, Hocott JB, Ebert RV. The collagen and elastin content of the lung in emphysema. Ann Intern Med. $1961 ; 55: 210-22$.

19. Kuhn C 3rd, Tavassoli F. The scanning electron microscopy of elastase-induced emphysema. A comparison with emphysema in man. Lab lnvest. 1976 Jan;34(1):2-9.

20. Finlay GA, O’Donnell MD, O'Connor CM, Hayes JP, FitzGerald MX. Elastin and collagen remodeling in emphysema. A scanning electron microscopy study. Am J Pathol. 1996;149(4):1405-15.

21. Kucich U, Christner P, Lippmann M, Fein A, Goldberg A, Kimbel $P$, et al. Immunologic measurement of elastinderived peptides in human serum. Am Rev Respir Dis. 1983;127(2):S28-30.

22. Stone PJ, Gottlieb DJ, O'Connor GT, Ciccolella DE, Breuer $\mathrm{R}$, Bryan-Rhadfi J, et al. Elastin and collagen degradation products in urine of smokers with and without chronic obstructive pulmonary disease. Am J Respir Crit Care Med. 1995;151(4):952-9.
23. Niewoehner DE, Kleinerman J. Morphometric study of elastic fibers in normal and emphysematous human lungs. Am Rev Respir Dis. 1977;115(1):15-21.

24. Bignon J, Khoury F, Even P, Andre J, Brouet G. Morphometric study in chronic obstructive bronchopulmonary disease. Pathologic, clinical, and physiologic correlations. Am Rev Respir Dis. 1969;99(5):669-95.

25. Matsuba K, Thurlbeck WM. The number and dimensions of small airways in emphysematous lungs. Am J Pathol. 1972;67(2):265-75.

26. Bignon J, Laurent $P$, de Cremoux H, Kouzan S. Critical review on small airway dysfunction. Eur J Respir Dis Suppl. 1986;146:345-58.

27. McLaughlin RF, Tueller EE. Anatomic and histologic changes of early emphysema. Chest. 1971;59(6):592-9.

28. Saetta M. Airway inflammation in chronic obstructive pulmonary disease. Am J Respir Crit Care Med. 1999;160(5 Pt 2):S17-20.

29. Garssen J, Nijkamp FP, Van Vugt E, Van der Vliet H, Van Loveren $\mathrm{H}$. T cell-derived antigen binding molecules play a role in the induction of airway hyperresponsiveness. Am J Respir Crit Care Med. 1994;150(6 Pt 1):1528-38.

30. De Jongste JC, Mons H, Block R, Bonta ll, Frederiksz AP, Kerrebijn KF. Increased in vitro histamine responses in human small airways smooth muscle from patients with chronic obstructive pulmonary disease. Am Rev Respir Dis. 1987;135(3):549-53. 